\title{
Pendidikan Akhlak Siswa dalam Kegiatan Ekstra
}

\author{
Oleh: \\ Umi Choiriah \\ (MA Abdulloh Mojo Kediri)
}

\begin{abstract}
Abstrak
Tulisan ini bertujuan menjelaskan pelaksanaan pendidikan akhlak siswa melalui pembiasaan kegiatan ekstra, dan. pembiasaan kegiatan ekstra dalam menunjang pendidikan akhlak. Penelitian ini merupakan penelitian kualitatif deskriptif. Penelitian ini merupakan studi kasus yang bermaksud menemukan makna, menyelidiki proses dan memperoleh pengertian dan pemahaman yang mendalam dari individu, kelompok atau situasi. Pengumpulan data menggunakan observasi, dokumentasi dan wawancara. Hasil penelitian, yaitu: (1) Pelaksanaan pembiasaan kegiatan ekstra yang diterapkan sangat baik dan berdampak terhadap pendidikan akhlak siswa, dan (2). Pembiasaan kegiatan ekstra dalam menunjang pendidikan akhlak siswa yakni: akhlak terhadap Allah SWT, akhlak terhadap sesama manusia, akhlak terhadap diri sendiri, meliputi; disiplin waktu, membuat hati tenang, tawaduk, rendah hati dan dermawan.
\end{abstract}

Kata Kunci: Pendidikan Akhlak, Pembiasaan Kegiatan Ekstra

\section{Abstract}

This article aims to explain the implementation of moral education of students through habituation extra activities, and habituation extra activities in support of moral education. This research is qualitative descriptive. This research is a case study that intends to find meaning, to investigate the process and gain insight and deep understanding of individuals, groups or situations. The collection of data through observation, documentation and interview. The results of the study, namely: (1) Implementation of habituation extra activities are 
implemented very well and has affected the moral education of students, and (2). Habituation extra activities in supporting the moral education of students namely: the morals against Allah, to fellow human morals, morals about yourself, include; time discipline, make the heart calm, tawaduk, humble and generous.

Keywords: Moral Education, Event Habituation Extras

\section{Pendahuluan}

Berkembangnya IPTEK di zaman modern ini, selain menawarkan berbagai kemudahan dan kenyamanan hidupjuga membuka peluang untuk melakukan kejahatan lebih canggih jika ilmu pengetahuan dan tekhnologi itu disalah gunakan. Kemampuan tekhnologi di bidang telekomunikasi misalnya, disamping memberi kemudahan juga dapat disalahgunakan untuk mendukung kegiatan jaringan kejahatan (Aminuddin dkk, 2005).

Seseorang yang memiliki ilmu pengetahuan dan tekhnologi yang maju dan disertai akhlak yang mulia, niscaya ilmu pengetahuan dan tekhnologi modern yang ia miliki itu akan dimanfaatkan sebaik-baiknya untuk kebaikan hidup manusia. Sebaliknya, orang yang memiliki ilmu pengetahuan dan tekhnologi modern namun tidak disertai dengan akhlak yang mulia, maka semuanya itu akan disalahgunakan yang akibatnya akan menimbulkan bencana di muka bumi (Nata, 2013).

Melihat fenomena seperti itu pendidikan akhlak sangat dibutuhkan bagi generasi muda khususnya di sekolah untuk tampil dengan citra ibadah yang kokoh, serta teguh di dalam menegakkan amar ma'nüf nahi munkar. Pendidikan akhlak merupakan bagian dalam pendidikan Islam sehingga salah satu fokus penting dalam pendidikan Islam adalah pendidikan akhlak. Pendidikan akhlak adalah bagian dari pendidikan Islam yang bertujuan membentuk pribadi muslim seutuhnya, mengembangkan seluruh potensi manusia dan menumbuhkan hubungan harmonis setiap individu dengan Allah, sesama manusia dan alam semesta.

Proses pendidikan tidak hanya melalui pendidikan yang dilakukan melalui tatap muka saja. Akan tetapi, bisa juga 
dilakukan melalui pembiasaan sejak usia dini yakni dengan selalu mengajarkan anak untuk berperilaku yang baik dan taat pada norma hukum yang berlaku.Indikasi bahwa akhlak dapat dipelajari dengan pembiasaan, meskipun pada awalnya anak didik menolak atau terpaksa melakukansuatu perbuatan atau akhlak yang baik, tapi setelah lama dipraktekkan secara terus-menerus dibiasakan akhirnya anak mendapatkan akhlak mulia.

Pembiasaan yang dimaksud dalam penelitian ini adalah sesuatu yang dibiasakan dari pihak sekolah bagi seluruh peserta didik dalam mengamalkan ajaran agama Islam terutama di lingkungan sekolah, seperti membiasakan berdoa sebelum dan sesudah belajar, mengucap salam ketika bertemu, membaca al-Qur'an sebelum pelajaran dimulai, salatzuhur berjamaah, berjabat tangan dan mencium tangan guru serta kegiatan-kegiatan ekstra lainnya yang dapat menunjang pendidikan akhlak anak.

Sekolah merupakan salah satu lingkungan yang memberikan pengaruh besar dalam pendidikan akhlak. Sekolah merupakan lembaga pendidikan yang berorientasi menjadikan para siswa terdidik sebagai generasi bangsa, mampu berfikir cedas, maju dan siap bersaing di tengah masyarakat modern dengan bekal akhlāqal-Karimah.

Sehubungan dengan hal tersebut di atas, MA Abdulloh adalah salah satu madrasah yang mempunyai perhatian terhadap pendidikan akhlak yang dilakukan melalui pembiasaan kegiatan ekstra. Hal ini dapat dibuktikan dengan adanya pelaksanaan pembiasaan kegiatan-kegiatan yang diharapkan dapat menunjang pendidikan akhlak siswa, seperti diadakannya pembiasaan membaca surah yasin sebelum pelajaran dimulai, salat zuhur berjamaah, pengumpulan dana sosial dan lain-lain.

\section{Metode Penelitian}

Penelitian ini merupakan penelitian kualitatif. Penelitian ini merupakan studi kasus yang bermaksud menemukan makna, menyelidiki proses dan memperoleh pengertian dan pemahaman yang mendalam dari individu, kelompok atau situasi (Emzir, 2012). 
Peneliti merupakan instrumen kunci dalam menangkap data sekaligus pengumpul data.Kehadiran peneliti di latar penelitian untuk menemukan dan mengeksplorasi data-data yang terkait dengan penelitian yang didekati dengan observasi sehingga peneliti merupakan observer penuh.Pengumpulan Data dalam penelitian ini menggunakan:

a. Wawancara (interview)

Jenis wawancara yang penulis gunakan adalah wawancara bebas terpimpin, yaitu wawancara dimana peneliti menggunakan pedoman wawancara seperlunya. Jenis wawancara yang penulis gunakan adalah wawancara secara mendalam, yaitu pertemuan langsung secara berulang-ulang dengan sumber data yang diarahkan pada pertanyaan. Adapun pihak yang akan peneliti wawancarai adalah kepala madrasah, waka kesiswaan, guru BP, siswa dan pihak lain yang terkait dengan tema yang penulis tentukan.

b. Metode Observasi

Penelitian ini merupakan observasi non-partisipan, yaitu observer tidak ikut dalam kehidupan orang yang diobservasi dan secara terpisah berkedudukan selaku pengamat saja (Emzir, 2012).

c. Metode Dokumentasi

Metode ini dimaksudkan untuk memperoleh data atau informasi yang tidak ditemukan dalam wawancara dan observasi, misalnya sejarah berdiriMA Abdulloh Mojo Kediri, struktur organisasi, keadaan siswa, keadaan guru dan pembantu, sarana-prasarana yang dimiliki dan lainlain.

Teknik analisis data dipakai setelah data selesai dikumpulkan, dikerjakan dan dimanfaatkan sedemikian rupa sampai berhasil menyimpulkan kebenaran yang dapat dipakai untuk menjawab persoalan yang digunakan dalam penelitian. Adapun analisis yang digunakan adalah metode deskriptif kualitatif, yaitu setelah semua data yang diperlukan telah terkumpul kemudian disusun dan diklasifikasikan, selanjutnya dianalisis kemudian diintepretasikan dengan kata-kata sedemikian rupa untuk menggambarkan objek-objek 
penelitian disaat penelitian dilakukan, sehingga dapat diambil kesimpulan secara proporsional dan logis.

\section{Hasil Penelitian}

Pendidikan akhlak merupakan usaha yang sangat terpuji dan sangat mulia. Bentuk-bentuk pendidikan akhlak siswa melaluipembiasaan kegiatan ekstra adalah proses internalisasi program yang dimaksudkan untuk menanamkan nilai-nilai akhlak di luar pokok bahasan dalam mata pelajaran atau diklat.

Pola pendidikan pembiasaan kegiatan ekstra bukan merupakan kegiatan yang menjadi tuntutan dalam kurikulum dan terbatas sebagai penunjang kegiatan intrakurikuler, namun kegiatan tersebut mempunyai peranan dan makna yang amat strategis bagi keberlangsungan pendidikan akhlak yang dilakukan sekolah.Demikian halnya, pendidikan akhlak melalui pembiasaan kegiatan ekstra di MA Abdulloh adalah cara yang dilakukan oleh pihak madrasah dalam upaya mendidik akhlak siswa agar sesuai dengan ajaran agama Islam yang mulia.

Tujuan diterapkan pembiasaan kegiatan ekstra adalah untuk melatih serta membiasakan anak didik berperilaku dan berakhlak mulia secara konsisten dan kontinyu, sehingga benar-benar tertanam pada diri anak dan akhirnya menjadi kebiasaan yang sulit ditinggalkan di kemudian hari. Oleh karena itu, dalam rangka meningkatkan dan melestarikan akhlak diperlukan bentuk-bentuk aktifitas yang dapat dibiasakan dan menjadi kebiasaan anak didik sejak dini sampai meninggal dunia.

\section{Pelaksanaan Pendidikan Akhlak Siswa Melalui Pembiasaan Kegiatan Ekstra}

1) Salat Zuhur Berjamaah

Salat zuhur berjamaah wajib dilakukan oleh seluruh siswa di MA Abdulloh Sukoanyar Mojo Kediri. Salat zuhur berjamaah dilakukan pada pukul 11.45 WIB dan bertempat di musalamadrasah. Imam bertugas sebagai imam dalam salat sekaligus memimpin berzikir dan berdoa bersama sesudah salat. Imam salat zuhur ini tidak dijadwalkan untuk guru, 
melainkan langsung dari pengasuh/ketua yayasan pendiri MA Abdulloh. Sedangkan guru piket bertugas untuk mengawasi jalannya salat dan menertibkan para siswa sebelum dan sesudah jamaah berlangsung.

2) Pembacaan Surah Yasin Sebelum Pelajaran Dimulai

Pembacaan surah yasin biasanya dilakukan 15 menit sebelum pelajaran dimulai yang dipandu oleh guru mengajar pada jam pertama. Cara membacanya dilakukan secara bersama-sama. Akan tetapi, apabila gurunya belum hadir, maka kegiatan tersebut berjalan sendiri dengan dipimpin oleh ketua kelas.

Tujuan diadakannya pelaksanaan pembacaan surah yasin sebelum pelajaran dimulai dijelaskan oleh waka kesiswaan, yaitu agar siswa gemar membaca al-Qur'an dan setidaknya siswa-siswi dapat hafal surah yasin dengan terbiasa membacanya setiap hari.Selain itu, pembacaan surah yasin yang dilakukan secara berjamaah membuat siswa-siswi sangat antusias dalam pembacaan surah yasin tersebut.

3) Pembacaan Doa Sebelum dan Sesudah Memulai Pelajaran

Kegiatan membaca doa sebelum dan sesudah pelajaran merupakan pembiasaan yang diwajibkan bagi semua siswasiswi MA Abdulloh Sukoanyar Mojo Kediri. Kegiatan tersebut dipimpin oleh ketua kelas setelah guru yang akan mengajar masuk kelas. Sebelumnya mereka membaca yasin bersama, baru setelah itu mulai berdo'a.

Kegiatan di atas bertujuan agar anak didik mempunyai kebiasaan selalu berdoa ketika akan memulai dan mengakhiri aktifitas/kegiatan. Selain itu, peserta didik secara tidak langsung dibiasakan untuk selalu bersyukur kepada Allah terhadap segala nikmat yang telah diberikan-Nya dengan mengingat Allah di manapun berada dan menjalankan perintah-Nya serta menjauhi larangan-Nya.

4) Berjabat Tangan dan Mengucapkan Salam

Kegiatan berjabat tangandan mengucapkan salam bertujuan agar di antara sesama warga madrasah terjalin hubungan yang harmonis dan dinamis. Pembiasaan ini adalah salahy satu cara yang digunakan untuk membiasakan anak terdidik tawaduk pada guru dimanapun mereka berada. 
Semua warga madrasah dibiasakan untuk mengucapkan salam dan berjabat tangan setiap bertemu dengan para guru, karyawan dan siswa. Berjabat tangan dilakukan antara perempuan dengan perempuan, dan laki-laki dengan laki-laki. Hal ini biasanya dilakukan pada setiap pagi, awal memasuki lingkungan madrasah.

5) Pengumpulan Dana Sosial

Selain uang kas pada masing-masing kelas, setiap seminggu sekali yaitu setiap hari jumat, peserta didik dianjurkan mengumpulkan dana sosial. Jumlah besar kecilnya tidak ditentukan, tetapi menurut kadar kemampuan dan keikhlasan masing-masing siswa. Pelaksanaan kegiatan ini diserahkan kepada masing-masing kelas, biasanya dikoordinir oleh ketua kelas. Setelah dana terkumpul maka salah satu perwakilan kelas menyerahkannya kepada petugas piket dan dari petugas piket diserahkan kepada pemegang dana sosial.

Kegiatan inibertujuan agar para siswa mempunyai rasa kepedulian sosial yang tinggi terhadap nasib saudara-saudara atau teman mereka. Kegiatan ini tentunya sangat bermanfaat untuk melatih mereka berbuat baik terhadap sesama, tolong menolong sesama muslim, serta dapat memberikan sesuatu dengan ikhlas sebagai rasa syukur kepada Allah SWT.

Pengumpulan dana sosialdi MA Abdulloh ini dijadwalkan pada hari jumat. Alasan pemilihan hari jumat ini karenasalah satu keistimewaan yang ada pada hari jumat segala kebaikan akan dilipatgandakan dan semua doa dikabulkan oleh Allah SWT.

\section{Pembiasaan Kegiatan Ekstra Dalam Menunjang Pendidikan Akhlak Siswa}

1) Salat Zuhur Berjamaah

Berdasarkan observasi yang peneliti lakukan, peneliti menyimpulkan bahwa salat zuhur berjamaah dapat membiasakan peserta didik untuk disiplin, karena pada dasarnya seorang yang melakukan salat berjamaah dituntut untuk bisa memanfaatkan waktu sebaik mungkin. Selain itu salat berjamaah dapat mempererat tali silaturahmi, yaitu dengan dilakukannya salat berjamaah membiasakan 
pesertanya untuk selalu berinteraksi dengan peserta yang lain. Hal ini merupakan tujuan manusia sebagai makhluk sosial.

2) Pembacaan Surah Yasin Sebelum Pelajaran Dimulai

Surah yasin merupakan qalb dari al-Qur'an, sebab surah yasin mempunyai banyak faedah, diantaranya: sebagai obat seluruh penyakit, memanjangkan umur, meringankan siksa kubur, memperbanyak rezeki dan lain-lain.Pembacaan surah yasin sebelum pelajaran dimulai dapat membuat hati tenang, sehingga proses belajar mengajar menjadi maksimal. Selain itu pembacaan yasin yang dilakukan secara berjamaah akan menumbuhkan semangat yang tinggi pada anak.

3) Pembacaan Doa Sebelum dan Sesudah Memulai Pelajaran

Pembacaan doa sebelum dan sesudah memulai pelajaranbertujuan agar anak didik mempunyai kebiasaan selalu berdoa ketika akan memulai dan mengakhiri aktifitas/kegiatan. Selain itu, peserta didik secara tidak langsung dibiasakan untuk selalu bersyukur kepada Allah terhadap segala nikmat yang telah diberikan-Nya dengan mengingat Allah di manapun berada dan menjalankan perintah-Nya serta menjauhi larangan-Nya. Kebiasaan semacam ini dapat membuat jiwa menjadi tenang, sehingga akan menyebabkan fikiran jernih yang akan berdampak baik terhadap kegiatan yang akan dilakukan.

4) Berjabat Tangan dan Mengucapkan Salam

Berjabat tangan dan mengucapakan salam merupakan suatu pekerjaan yang dianjurkan agama Islam. Pembiasaan ini mempunyai nilai-nilai positif yang berdampak bagi pendidikan akhlak, diantaranya mempererat tali silaturahmi dan menumbuhkan kepedulian sosial yang tinggi, dengan adanya silaturahmi yang terjaga dapat meminimalisir kasus tawuran diantara pelajar. Sedangkan dengan adanya kepedulian sosial yang tinggiakan memberikan dampak saling tolong menolong diantara sesama pelajar maupun guru.Dampak positif lain dari pembiasaan berjabat tangan dan mengucapkan salam adalah melatih diri untuk berani berinteraksi dengan masyarakat.

5) Pengumpulan Dana Sosial 
Pembiasaan infak yang dilakukan di MA Abdulloh setiap hari jumat mengajarkan siswa selalu tolong menolong terhadap sesama dan mempunyai rasa kepedulian yang tinggi. Ketika peneliti melakukan observasi, peneliti menemukan seorang siswa yang meminjamkan alat tulis kepada temannya ketika mengetahuitemannyatidakmembawanya.Hal tersebut mencerminkan akhlak terhadap sesama, yaitu rasa kepedulian yang tinggi.

Hal yang serupa juga dijelaskan oleh salah satu alumni MA Abdulloh, bahwa adanya program pembiasaan infak di sekolah secara tidak langsung mengajarkan untuk memiliki rasa kepedulian yang tinggi dan lebih peka terhadap lingkungan sekitar yang membutuhkan bantuan tenaga maupun materi.

\section{Faktor Pendukung Dan Penghambat Pendidikan Akhlak Siswa}

1) Faktor Pendukung

Faktor pendukung dalam pendidikan akhlak siswa di MA Abdulloh adalah keadaan lingkungan madrasah yang strategis, yaitu MA Abdulloh berada dalam satu lingkup dengan Yayasan Islam Abdulloh yang notabenenya berbasis pesantren. Bagi anak yang berada dalam lingkup pesantren akan lebih mudah dalam mendidik akhlaknya dibandingkan dengan anak yang hanya berada pada lembaga pendidikan formal.

Orang tua juga merupakan pihak terpenting dalam pelaksanaan pendidikan akhlak, karena waktu pendidikan yang diberikan pada anak lebih banyak dilakukan di rumah dengan keluarga dibandingkan di sekolah. Oleh karena itu, MA Abdulloh selalu mengundang orang tua murid dua kali dalam setahun untuk melakukan musyawarah dalam usaha mendidik anak agar mempunyai akhlak yang lebih baik.

2) Faktor Penghambat

Faktor penghambat pendidikan akhlak siswa di MA Abdulloh diantaranya adalah fasilitas/sarana prasarana yang kurang memadai. Fasilitas/sarana prasarana yang kurang memadai dapat menjadi kendala kedislipinan siswa. Selain itu, orang tua/keluarga yang kurang peduli terhadap kegaiatan keagamaan anak juga dapat menghambat pendidikan akhlak 
siswa,seperti orang tua tidak salat, waktunya shalat subuh orang tua masih tidur, orang tua sibuk bekerja dan lain-lain.

\section{Pembahasan}

Berdasarkan hasil penelitian yang dilakukan oleh peneliti, maka dapat kami paparkan pembahasannya sebagai berikut:

a. Pelaksanaan Pendidikan Akhlak Siswa Melalui Pembiasaan Kegiatan Ekstra

Berdasarkan paparan data yang telah dipaparkan di atas, dapat peneliti simpulkan bahwa pelaksanaan pendidikan akhlak melalui pembiasaan kegiatan ekstra di MA Abdulloh sangat baik.Pembiasaan tersebut telah mengakar kuat bagi warga madrasah, hampir seluruh warga MA Abdulloh selalu melaksanakannya.Pembiasaan-pembiasaan tersebut sangat menunjang pendidikan akhlak siswa.

Pembiasaan-pembiasaan yang serupa juga terdapat di sekolah-sekolah yang lain, seperti pembiasaan salat zuhur berjamaah, pembacaan surah yasin sebelum pelajaran dimulai, pelaksanaan Sedekah Minimal Seribu (SMS) dan doa bersama yang dilakukan oleh warga MAN Purwoasri Kediri. Pembiasaan-pembiasaan tersebut telah menjadi pembiasaan yang selalu dilakukan oleh seluruh warga madrasah, sehingga dari pembiasaan-pembiasaan tersebut terciptalah akhlak yang baik bagi warga madrasah.

b. Pembiasaan Kegiatan Ekstra Dalam Menunjang Pendidikan Akhlak Siswa Di MA Abdulloh.

1) Pembiasaan Salat Zuhur Berjamaah

Berdasarkan observasi dan wawancara yang telah peneliti lakukan, bahwasannya pelaksanaan salat zuhur berjamaah dapatmembiasakan peserta didik untuk disiplin, karena pada dasarnya seorang yang melakukan salat berjamaah dituntut untuk bisa memanfaatkan waktu sebaik mungkin. Selain itu salat berjamaah dapat mempererat tali silaturahmi, yaitu dengan dilakukannya salat berjamaah membiasakan pesertanya untuk selalu berinteraksi dengan peserta yang lain. Hal ini merupakan tujuan manusia sebagai makhluk sosial. 
Hal yang serupa dijelaskan dalam penelitian terdahulu, yang menyatakan bahwa nilai yang dapat diambil dari pembiasaan jamaah salat zuhur adalah sebagai berikut:

a) Aspekpendidikan

Salat berjamaah mengajarkan sikap kedisiplinan. Hal ini bisa dilihat dari adanya kedisiplinan waktu dalam melaksanakannya. Ketika azan berku mandang, praktis para warga madrasah yang melakukan shalat berjamaah akan bergegas menuju masjid pada waktu itu juga.

Selain itu, salat yang dilaksanakan secara berjamaah juga mendidik kita untuk menghilangkan sikap egoisme, sebab kita tidak mungkin mengikuti kemauan kita untuk rukuk mendahului imam atau melakukan salam lebih dini. Akan tetapi kita dituntut taat mengikuti gerak-gerik seorang imam. Oleh karena itu, semakin kita sering salat berjamaah maka semakin terdidik diri kita untuk mengendalikan atau melunakan sikap egois mepada diri kita.

b) Aspek sosial

Salat berjamaah merupakan manifestasi dari ittihād alMuslim (bersatunya umat islam) tanpa adanya pecah belah di antara mereka dan tanpa memandang derajat antara kaya atau miskin. Bersatu padu dalam komando seorang imam. Selain itu, ibadah salat yang dilakuan secara jamaah akan mencipatankan rasa empati terhadap sesama, sehingga tercipta sebuah rasa kasih sayang antar sesama muslim yang berawal dari taaruf (saling mengenal).

Sebagai gambaran nyata, masyarakat saat ini pada umumnya disibukan dengan berbagai aktifitas sehari-hari, akan tetapi dengan adanya salat berjamaah maka akan memberikan solusi untuk saling mengenal dan menjalin silaturahmi menjadi dekat antar sesama warga madrasah baik hubungan guru dengan guru, hubungan siswa dengan siswa maupun hubungan guru dengan siswanya (Abidah, 2013).

2) Pembiasaan Pembacaan Surah Yasin Sebelum Pelajaran

Dimulai

Berdasarkan pengamatan peneliti, kegiatan pembacaan yasin bertujuan agar para siswa-siswi MA Abdulloh dapat membaca al-Qur'an dengan lancar sehingga mereka gemar 
membacanya dan dapat menjadi kebaiasaan baik serta agar anak hafal bacaan surah yasin dengan terbiasa membacanya, sehingga dapat menjadi bekal kelak mereka terjun ke masyarakat.

Pembacaan surah yasin sebelum pelajaran dimulai dapat membuat hati tenang, sehingga proses belajar mengajar menjadi maksimal. Selain itu, pembacaan yasin yang dilakukan secara bersama-sama akan menumbuhkan rasa persaudaraan yang kuat.

Lina Nur Abidah (2013) menjelaskan dalam hasil penelitiannya, bahwa Membaca al-Qur'an merupakan bentuk peribadatan yang diyakini dapat mendekatkan diri kepada AllahSWT, meningkatkan keimanan dan ketakwaan yang berimplikasi pada sikap dan perilaku yang positif, dapat mengontrol diri, mendapat ketenangan, lisan terjaga dan istikamah dalam beribadah. Melalui kegiatan membacaalQur'an para siswa dapat menumbuhkan sikap luhur sehingga berpengaruh terhadap peningkatan prestasi belajar dan juga dapat membentangi diri dari pengaruh negatif (Abidah, 2013).

Motivasi membaca al-Qur'an atau khususnya surat yasin ini karena al-Qur'an tidak lain sebagai pedoman hidup bagi manusia, apabila seorang hamba membaca ayat al-Qur'an akan mendapatkan pahala yang banyak dimana satu huruf diberi balasan dengan sepuluh kebajikan. Membaca surat yasin rutin setiap harinya akan memberikan manfaat yakni diberikan jalan kemudahan, petunjuk dan senantiasa ingat kepada Allah SWT (Abidah, 2013). Berdasarkan uraian di atas dapat peneliti simpulkan, bahwa kegiatan ekstra pembacaan yasin dapat menunjang pendidikan akhlak peserta didik.

3) Pembiasaan Membaca Doa Sebelum Dan Sesudah Belajar

Penerapan pembiasaan membaca doa sebelum dan sesudah belajarmembiasakan peserta didik untuk selalu bersyukur kepada Allah terhadap segala nikmat yang telah diberikan-Nya dengan mengingat Allah di manapun berada dan menjalankan perintah-Nya serta menjauhi larangan-Nya.

Hal yang serupa dijelaskan dalam penelitian lain, bahwadengan membaca doa akan terjalin hubungan baik manusia dengan penciptanya. Hal ini merupakan salah satu 
akhlak manusia terhadap penciptanya, karena dengan membaca doa akan menumbuhkan rasa syukur dan terimakasih pada diri anak (Andriyani, 2014). Berdasarkan hasil penelitian-penelitian tersebut, maka pembacaan doa sebelum dan sesudah belajar adalah suatu perbuatan yang dapat mendidik akhlak peserta didik.

\section{4) Berjabat Tangan Dan Mengucapkan Salam}

Hasil penelitian yang dilakukan oleh peneliti, bahwa pelaksanaan pembiasaan berjabat tangan dan mengucapkan salam bagi warga Madrasah Aliyah Abdulloh sangat baik. Pembiasaan tersebut juga dapat menumbuhkan tali persaudaraan yang erat dan menunjukkan keakraban warga madrasah yang harmonis. Selain itu, adanya pembiasaan tersebut menunjukkan rasa hormat seorang murid terhadap gurunya.

Haryani Diyati dan Mulyadi (2014) menyatakan dalam penelitiannya bahwa, Kegiatan ini bertujuan untuk mendorong siswa datang tepat waktu di sekolah, tertib dalam berpakaian dan untuk menumbuhkan sikap saling hormat. Setelah cara ini diterapkan maka pelanggaran tata tertib dapat berkurang. Siswa menjadi sadar untuk mentaati tata tertib di sekolah bukan karena dimarahi oleh gurunya.

Pembiasaan ini dapat menumbuhkan dan mengembangkan sikap saling mencintai dan mengasihi, saling peduli dan pada gilirannya dapat meningkatkan kedisiplinan semangat pembelajaran (Tobroni, 2014). Hasil penelitian yang lain menyatakan bahwa dengan mengucapkan salam guru mendoakan peserta didik agar semangat dalam belajar dan dengan mengucapkan salam juga akan tertanam akhlak terpuji, saling peduli dan tercipta nilai kasih sayang (Andriyani, 2014).

\section{5) Pengumpulan Dana Sosial}

Pengumpulan dana sosial yang dilaksanakan di madrasah dan tidak ditentukan besar kecil jumlah uang yang diberikan siswa, akan menanamkansikap siswa yang mempunyai rasa kepedulian sosial yang tinggi terhadap nasib saudara-saudara atau teman mereka. Kegiatan ini tentunya sangat bermanfaat 
untuk melatih mereka berbuat baik terhadap sesama, tolong menolong sesama muslim, serta dapat memberikan sesuatu dengan ikhlas sebagai rasa syukur kepada Allah SWT.

Ramli dan Wiwik Wijayanti (2013), dalam penelitiannya menjelaskan bahwa Nilai peduli sosial di SMP Negeri 1 Pangkalan Kuras teritegrasi ke dalam mata pelajaran seperti siswa dibiasakan saling memberikan bantuan dalam hal kebaikan seperti meminjamkan alat-alat tulis kepada teman yang membutuhkan. Selain itu juga dikembangkan melalui pengumpulan infak oleh OSIS dan disumbangkan kepada keluarga yang mendapat musibah. Kondisi ini sesuai dengan nilai-nilai peduli sosial yaitu sikap dan tindakan yang selalu ingin memberi bantuan pada orang lain dan masyarakat yang membutuhkan.

Pengumpulan dana sosial/memberi infak adalah wujud penanaman jiwa sosial kepada anak. Peduli terhadap sesama dengan memberikan sebagian yang dia miliki. Memberikan infak berarti anak belajar berbagi, membagi milik dan kesenangannya kepada orang lain. Kelak jika dia tumbuh menjadi pemimpin maka dia akan menjadi pemimpin yang memiliki jiwa sosial yang tinggi dengan sikap senang memberi (dermawan), dan menjauhkan diri dari keangkuhan (Listiyana, 2012).

Berinfak mengajarkan agar kita banyak bersyukur atas nikmat yang diberikan oleh Allah SWT, belajar bahwa apa yang dimiliki saat ini hanyalah titipan yang suatu saat bisa diminta lagi oleh pemiliknya, seperti hilangnya harta benda. Berinfak juga mengajarkan agar manusia menyakini petunjuk kebenaran tentang satu perbuatan baik akan dibalas dengan sepuluh kebaikan bahkan dilipatgandakan menjadi 700 kebaikan.

Selain itu berinfak juga mengajarkan bahwa ada perputaran nasib sebagaimana ada perputaran harta benda dari milik kita yang jika dibelanjakan akan menjadi milik orang lain. Berinfak juga mengajarkan bahwa apa yang ada di dunia ini semua bersifat sementara. Karenanya kecintaan terhadap dunia harus diarahkan kepada jalan yang benar. Bukan nilai uang infak yang diajarkan tapi, pemupukan jiwa 
dermawan itu adalah nilai yang paling utama (Listiyana, 2012).

Berdasarkan uraian yang telah dipaparkan di atas dapat penulis simpulkan bahwa pembiasaan kegiatan ekstrakurikuler yang diterapkan di Madrasah Aliyah Abdulloh Mojo Sukoanyar Kediri terlaksana dengan baik. Pembiasaan kegiatan ekstra tersebut adalah merupakan kegiatan yang dapat menunjang pendidikan akhlak siswa. Berikut penulis sajikan pembiasaan kegiatan ekstra dalam menunjang pendidikan akhlak siswa di MA Abdulloh dalam bentuk gambar 1.

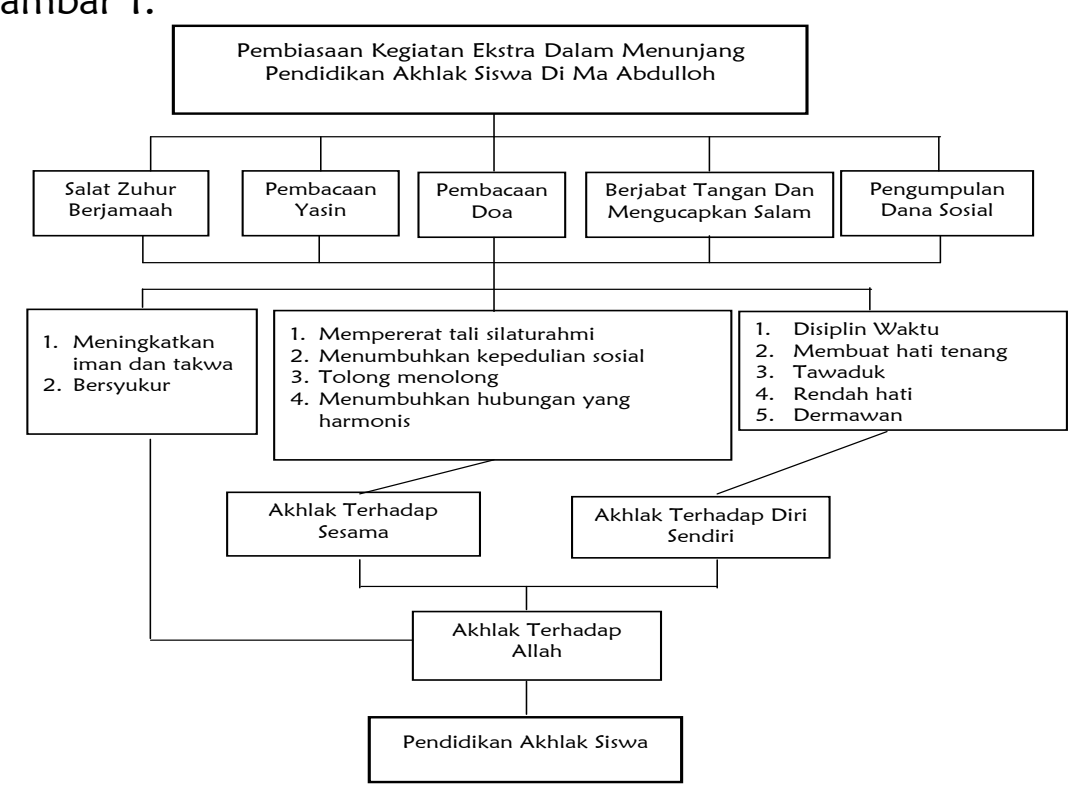

Gambar 1. Pembiasaan Kegiatan Ekstra Dalam Menunjang Pendidikan Akhlak Siswa

\section{Penutup \\ Kesimpulan}

Setelah melakukan kajian penelitian tentang pendidikan akhlak siswa melalui pembiasaan kegiatan ekstra di MA Abdulloh, peneliti mengambil kesimpulan sebagai berikut:

1. Pelaksanaan Pendidikan Akhlak Melalui Pembiasaan Kegiatan Ekstra

Pendidikan akhlak melalui pembiasaan kegiatan ekstra di MA Abdulloh adalah salah satu cara yang dilakukan oleh pihak madrasah dalam upaya mendidik akhlak siswa agar 
sesuai dengan ajaran agama Islam yang mulia.Pelaksanaan pembiasaan kegiatan ekstra yang diterapkan di MA Abdulloh sangat baik dan berdampak terhadap pendidikan akhlak siswa.

Pembiasaan kegiatan ekstra yang diterapkan di MA Abdulloh diantaranya adalah; program salat zuhur berjamaah, pembacaan surah yasin sebelum pelajaran dimulai, membaca doa sebelum dan sesudah pelajaran, pengumpulan dana sosial, berjabat tangan dan mengucapkan salam sewaktu bertemu teman, guru, maupun karyawan, melaksanakan ziarah kubur pendiri yayasan dua kali dalam setahun, mewajibkan semua warga madrasah putra-putri berpakaian rapi dan sopan setiap hari dan melaksanakan peringatanperingatan hari besar agama Islam dengan melibatkan semua warga sekolah.

2. Pembiasaan Kegiatan Ekstra Dalam Menunjang Pendidikan Akhlak Siswa Di MA Abdulloh

Pembiasaan kegiatan ekstra dalam menunjang pendidikan akhlak siswa di MA Abdulloh menghasilkan; a) akhlak terhadap Allah SWT, yaitu akhlak selalu bersyukur kepada Allah terhadap segala nikmat yang telah diberikanNya dengan mengingat Allah di manapun berada dan menjalankan perintah-Nya serta menjauhi larangan-Nya, b) akhlak terhadap sesama manusia, meliputi; menumbuhkan rasa kepedulian yang tinggi, saling tolong menolong, saling menyayangi, dan menumbuhkan sikap sopan santun terhadap guru, orang tua dan lain-lain, c) akhlak terhadap diri sendiri, meliputi; disiplin waktu, membuat hati tenang, tawaduk, rendah hati dan dermawan.

\section{Saran}

Dari hasil penelitian yang peneliti lakukan tentang pendidikan akhlak siswa melalui pembiasaan kegiatan ekstra di MA Abdulloh, maka saran peneliti adalah:

1. Diharapkan kepada guru, khususnya guru agama Islam untuk dapat dijadikan contoh/tauladan yang baik terhadap pembiasaan kegiatan ekstra di MA Abdulloh sehingga nilai- 
nilai tersebut dapat tertanam dengan baik pada diri peserta didik.

2. Diharapkan kepada para guru (guru piket dan guru BP) untuk dapat lebih tegas dalam menertibkan siswa dan memberi sanksi bagi yang melanggar tata-tertib dan yang tidak melaksanakan pembiasaan yang diterapkan, sehingga peserta didik mempunyai kesadaran yang tinggi dan bertanggung-jawab.

3. Bagi para siswa diharapkan untuk aktif mengikuti dan melaksanakan kegiatan-kegiatan keagamaan sehingga bertambah pengetahuan agamanya dan dapat memahami dan menghayati nilai-nilai yang terkandung di dalamnya serta diamalkan dalam kehidupan sehari-hari.

\section{Daftar Pustaka}

Abidah, Lina Nur. "Efektivitas ProgramEkstrakurikuler KeagamaanDalamPembentukanMoralitas SiswaDiMAN PurwoasriKediri". Skripsi tidak diterbitkan. Surabaya: Institut Agama Islam Negeri Sunan Ampel, 2013.

Aminuddin dkk.Pendidikan Agama Islam. Bogor: Chalia Indonesia, 2005.

Diyati, Haryani dan Muhyadi, "Peran Kepemimpinan Kepala SekolahDalam Pengembangan Budaya SekolahDi SDN Kwayuhan, Kecamatan Minggir, Sleman", Jurnal Akutabilitas Manajemen Pendidikan,(online), Volume.2, No.1, (http://eprints.uny.ac.id/12536, diakses 2014).

Emzir.Metodologi Penelitian Kualitatif Analisis Data. Jakarta: Raja Grafindo Persada, 2012.

Listiyana, Heni. "Membangun Karakter Siswa Madrasah Ibtidaiyah", Jurnal PGMI Madrasatuna, (online), Volume. $\quad 04, \quad$ No.1 (http://madrasatuna.uinsby.ac.id/index.php, diakses September 2012).

Nata, Abbudin.Akhlak Tasawuf. Jakarta: PT Grafindo Persada, 2013. 
86 Pendidikan Akhlak Siswa

Ramli, Wiwik Wijayanti, "Implementasi Pendidikan Karakter Di SMP Negeri 1 Dan Mts Al-Qasimiyah Kecamatan Pangkalan Kuras Kabupaten Pelalawan", Jurnal Akutabilitas Manajemen Pendidikan, (online), Volume.1, No.2, (Error! Hyperlink reference not valid., diakses 2013).

Ria Andriyani. "Pelaksanaan Pembinaan Akhlak Dalam Pembelajaran Bagi Siswa Tunagrahita”. Jurnal Ilmiah Pendidikan Khusus, (online), Volume 3, No.3, (http: //ejournal.unp.ac.id/index.php/jupekhu, diakses September 2014).

Tobroni, "Peranan Pendidikan Agama Dalam Pembentukan Etika Sosial Persaudaraan Dan Perdamaian", PROGRESIVA, (online), Volume.5, No.1, (diakses Desember 2014). 